\title{
Use of biological products in conditions of organic manufacture of soya
}

\author{
Gorodiskaya I. ${ }^{1}$, Plaksiuk L. ${ }^{2}$, Chub A. ${ }^{3}$ \\ Institute of agroecology and nature management of NAAS, Metrolohichna Str., 12, Kyiv, 03143, Ukraine; \\ e-mail: ${ }^{1}$ anni0479@gmail.com, ${ }^{2}$ larosmail1@gmail.com, ${ }^{3}$ artemchub@gmail.com
}

The purpose. To assess influence of application of biological products on development and density of segetal vegetation on organic crops of soya in view of change of agroclimatic parameters. Methods. Researches had been spent on the basis of Skvyra experimental station of organic manufacture of Institute of agroecology and nature management of NAAS during 2015-2017. They studied density of weeds on organic crops of soya of variety «Suziria» by means of quantitatively-weight account of segetal vegetation (according to O.V. Fisiunov) and determination of specific conformity of plants of weeds (according to I.V. Veselovskii). The area of leave surface of soya was determined according to Z.M. Gritsayenko. Statistical processing of experimental data was made according to B.A. Dospehov technique. Results. It is determined that under the influence of biological products physiological processes of plants of soya become more active. That increase the area of leave surface. It is noted that the soya actively competes with segetal vegetation for vital space, suppressing it. Result of stimulation of growth of soya under action of biological preparations is the increase in productivity of agricultural crop. Conclusions. Application of complex of biological products in conditions of transition period to organic manufacture promotes increase in competitiveness of cultural plant to segetal groupings and, as consequence, stabilization of agro-eco-system.

Key words: soya, organic manufacture, ecological assessment, segetal vegetation, biological products.

https://doi.org/10.31073/agrovisnyk201809-11

The important significance in formation of balanced agrocenosis, which functioned, by the principles of organic farming, is the factor of the phytosanitary state of the fields.

The most majority of segetal vegetation has a stronger adaptive potential than a cultivated plant. Grouping of weeds are genetically more resistant to droughts and excessive precipitation. The volume of possible damage of weeds varies depending on their species composition, the level of presence and duration of competitive relationships between them and cultivated plants [1]. They become a source of pest and disease multiplication.It was established that weeds in the amount of 20 plants per $1 \mathrm{~m} 2$ remove $135 \mathrm{~kg}$ of nitrogen, $40 \mathrm{~kg}$ of phosphorus and $150 \mathrm{~kg}$ of potassium per hectare, at that the absorption of nutrients by cereal weeds is lower by $20 \%$ than dicotyledonous [2].The loss of yields in case of a weediness from 25 to 50 days of vegetation in the amount of 10 pieces per square $1 \mathrm{~m} 2$ is from 28 to $35 \%$ [3]. At the same time, the organic system of agriculture is characterized by the highest losses of nutrients by segetal vegetation, compared with industrial and ecological systems [4].

However, studies by Professor Shevnikov M. Ya. [5] have proved that using mechanical methods for controlling segetal vegetation may reduce the permeability of soybean crops to $77 \%$.Tthere are also data on the possibility of reducing the contamination of crops by $6090 \%$ by pre-emergence harrowing [6]. Thus, preventive measures aimed at reducing the littering of fields and the proliferation of segetal vegetation in the transitional period to organic farming become key factors in reducing environmental risks in organic land use.

The system of combating weed groups in a transitional period should address the following tasks: reducing the seed germination of weeds, destroying weeds in the early stages, preventing the fruiting of weed groups and the mechanical destruction of root-weed weeds. Investigation of the dynamics of the quantitative and species composition of the seed vegetation in the transitional period to organic farming 
will enable to predict the structure of weed sinuses and the risks of loss of crop yields due to organic land use.

The purpose of the research is to assess the effect of the use of biopreparations on the development and density of segetal vegetation on organic soybeans, taking into account the change in agroclimatic parameters.

Materials and methods of research. The research was held on the basis of the Skvirsky research station of organic production of the Institute of Agroecology and Nature Management of NAAS during 2015-2017. The experimental area belongs to the Forest-steppe zone of the Right bank of Ukraine, that characterized by moderately continental, mild climate with a sufficient level of humidification. Nevertheless, the analysis of the weather indicators of the vegetative periods of 2015-2017 showed a generally accepted global trend of climate change. Thus, the vegetative periods of 2015-2017 were characterized by aride conditions (the amount of precipitation was $30-50 \%$ of the average long-term indicators) and the increased average daily temperatures (at 2-50C) toward in relation to the average annual values.

The scheme of experiment on the study of the influence of biopreparations on the development and density of segetal vegetation in soybean crops included the following variants:

Option 1 - control (no processing);

Option 2 - treatment with a set of biologics of OOO TD "Enzym-Agro" (presowing seed treatment with Biomag Soya preparations (bacterial nitrogen-fixing inoculant), Biofosforin (biotechnological preparation of prolonged action for improving phosphorus, potassium and nitrogen nutrition of plants, stimulation of root system growth, and disease prevention plants), Phytodoctor (biological fungicidal drug of a wide spectrum of action));

Option 3- 3 - treatment of the biological products by BTU-Center LLC (pre-sowing soil treatment with MikoKhelp (multifunctional microbial preparation with prolonged fungicidal action for soil improvement and protection of shoots from pathogens), Groundflex (ground biofertilizer for mobilization of phosphorus and potassium from insoluble compounds, fixation nitrogen), Enposam (biopreparation fertilizer for nutrition and plant protection) pre-sowing seed treatment with MikoHelp preparations, Organic balance (universal biopreparation for growth stimulation and development crops, increasing resistance to stress, diseases, pests and for a balanced diet) Azotofit-P (universal biopesticide for fertilizing plants) Enposam, Rizolayn (nitrogen-fixing bacteria inoculums).

The soil of the experimental site - the midle loam chernozem. The relief is smooth. The area of the experimental site is $0,11 \mathrm{ha}$. The repetition of the experiment is fourfold.

The study used a variety of soy Suziria. The study of weed density was carried out with the help of quantitative-weight accounting of segetal vegetation by Fisyunov O.V. [7, 8]. Determination of the species belonging to the plants was carried out using the reference book on weeds and atlas-determiner under Veselovsky IV. $[9,10]$. The area of the leaf surface of soy was determined according to Grytsaenko Z.M. Statistical processing of experimental data was carried out according to Dospekhov B.A.

Research results. According to the results of the study, soybean crops for three growing season $(2015,2016,2017)$ revealed the presence of the following types of weeds: amaranth

(Amaranthusretroflexus), yellow bristle grass (Setariaglauca), mountain bluet (Polygonum convolvulus ), corn bindweed (Convolvulus arvensis), barnyard grass (Echinochloa crus-galli), lamb's-quarters (Chenopodium album L.), canada thistle (Cirsiumarvense L), bitter winter cress (Barbarea vulgaris), corn speedwell (veronica hederifolia L.) .The species composition of segetal vegetation on soybean crops varied depending on the change in crop rotation due to the transition from the traditional to the organic production method and did not depend on the treatment of biological products.

The greatest species diversity was in 2015 . Were identified 10 species weed's seeds on soybean crops. At that, among the total number of weeds in soybeans was identified buckwheat the seeds (fallow) 
which came to the soil due through lack of efficiency of the harvesting process of buckwheat. In accordance with Figure 1, the share of buckwheat in soybeans was about $1.4 \%$.

In 2016-2017, soya was sown after winter wheat, which resulted in a decrease in the number of species weed to 5 species. The obtained data testify to the effectiveness of scientifically grounded crop rotation in combating weeds in the transitional period to organic production of crop production.

Studies have shown the dependence of the species composition of segetal vegetation in soybean crops on weather and climatic conditions.

Thus, in 2015, the dominant species of weeds was amaranth (40.39\%) (Fig. 1), and in subsequent years the dominant species was yellow bristle grass (64,70\% in 2016 and $68.20 \%$ in 2017 p.) (Figures 2, $3)$. The reason for this phenomenon could be weather conditions that prevailed on the explored territory in April-May 2015.

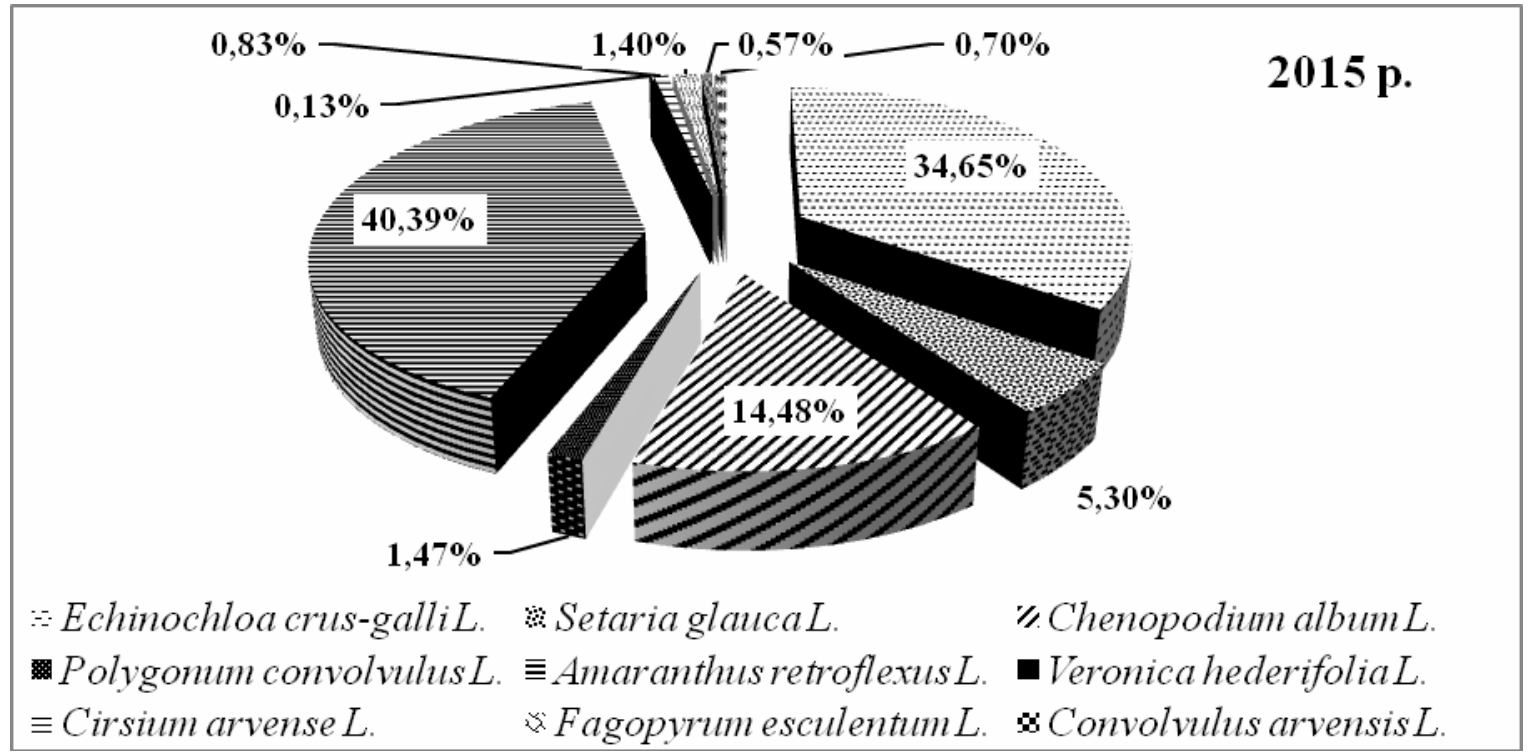

Fig. 1. Species composition of weeds on soybean crops, 2015

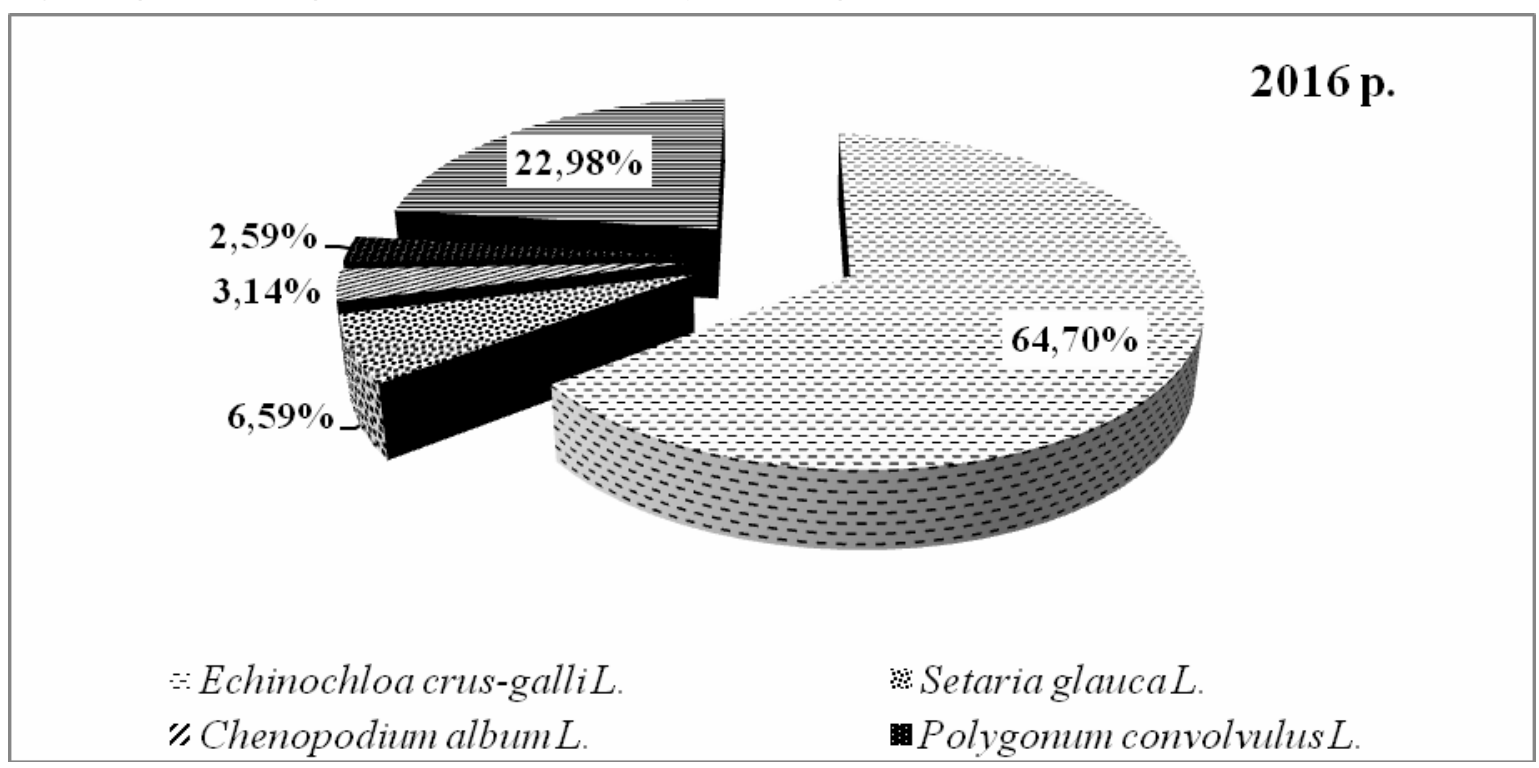

Fig. 2. Species composition of weeds on soybean crops, 2016 


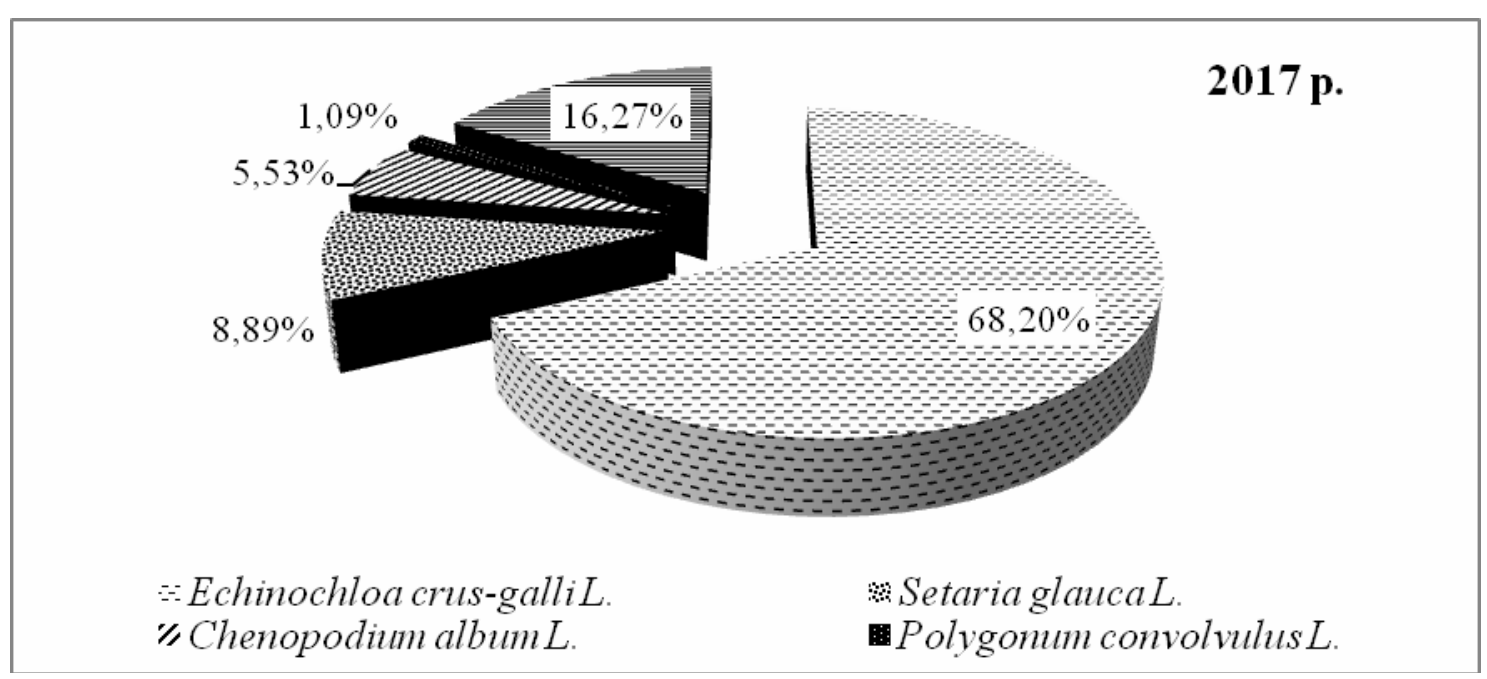

Fig. 3. Species composition of weeds on soybean crops, 2017

The spring months of 2015 were characterized by a lower (almost $2{ }^{\circ} \mathrm{C}$ ) temperature, compared with the following years of investigation (2016 and 2017), which led to a worse warming of the soil in the preseason and a decrease in the efficiency of early-stage agrotechnical techniques.

After all, the yellow bristle grass has a depth of germination of up to $14 \mathrm{~cm}$, and a amaranth germinated to $3 \mathrm{~cm}$. Warm, moderately humid April-May 2016-2017 contributed to the germination of spring weeds, which increased the effectiveness of pre-sowing tillage, aimed at combating segetal vegetation, as shown in Fig. 2-3.

In 2015, among the total number of weeds in buckwheat soybean, buckwheat was identified, the seeds (fallow) which were introduced into the soil as a result of the insufficient efficiency of the buckwheat harvesting process. According to Figure 1, part of the buckwheat in soybean crops was about $1.4 \%$.

As you know, with the formation of the optimal leaf area, agricultural plants are able to form high yields with good qualitative indicators [11].

The intensity of accretion the area of the leaf surface is determined by the density of plant standing and the content of nutrients in the soil. Both thickened and overly sparse crops are characterized by unsatisfactory conditions of plant growth and development. In particular, in thickened crops, competition increases both between plants, including with sesame vegetation, and within the plant itself (shading of the lower tiers). In rarefied crops, inefficient use of all available agrarian resources occurs and the problem of indigestion of crops is intensified [12].

Due to the considerable attention paid to the use of biological preparations for the organic farming practices system, our research has identified the effect of biopreparations on the area of soybean leaf area and its yield.

In the course of the research, a positive influence of treatment with biopreparations on the area of the leafy surface of soy was noted. Thus, in the variant with the use of the complex of biologies LTD TD "Enzim - Agro", the area of leafy soy surface, in relation to the control variant, increased by $6 \%$ in 2015 , by $8.5 \%$ - in 2016 and by $8.4 \%$ - in 2017 The option for treating soybeans with the complex of biopreparations PP "BTU-Center" showed a similar effect on the area of its leaf surface, which increased in 2016 by $3.8 \%$, in 2016 - by $5.4 \%$, and in 2017 - by 10, 2\% (Table 1 ). 
Table 1 - Influence of biologics on the development of soybean plants and weed groups

\begin{tabular}{|c|c|c|c|c|c|c|}
\hline \multirow{2}{*}{ Option } & \multicolumn{2}{|c|}{$2015 \mathrm{p}}$. & \multicolumn{2}{|c|}{$2016 \mathrm{p.}$} & \multicolumn{2}{|c|}{$2017 \mathrm{p.}$} \\
\cline { 2 - 6 } & $\begin{array}{r}\text { Area of } \\
\text { leafy surface of } \\
\text { soy, (thousand } \\
\mathrm{m} 2 / \text { ha) }\end{array}$ & $\begin{array}{r}\text { Weight } \\
\text { ratio of } \\
\text { soybeans to } \\
\text { weight weeds }\end{array}$ & $\begin{array}{r}\text { Area of leafy } \\
\text { surface of soy, } \\
\text { (thousand m2 / } \\
\text { ha) }\end{array}$ & $\begin{array}{r}\text { Weight } \\
\text { ratio of } \\
\text { soybeans to } \\
\text { weight weeds }\end{array}$ & $\begin{array}{r}\text { Area of leafy } \\
\text { surface of soy, } \\
\text { (thousand m2 / } \\
\text { ha) }\end{array}$ & $\begin{array}{c}\text { Weight } \\
\text { ratio of } \\
\text { soybeans to } \\
\text { weight weeds }\end{array}$ \\
\hline Control & $36,6 \pm 0,2$ & 0,9 & $44,4 \pm 0,4$ & 3,1 & $45,0 \pm 0,4$ & 6,7 \\
\hline $\begin{array}{l}\text { Treatment } \\
\text { with TD "Enzim } \\
\text { Agro" } \\
\text { preparations }\end{array}$ & $38,8 \pm 0,2$ & 1,2 & $46,8 \pm 0,5$ & 4,0 & $49,6 \pm 0,7$ & 7,1 \\
\hline $\begin{array}{l}\text { Treatment } \\
\text { with } \\
\text { Center" } \\
\text { preparations }\end{array}$ & $38 \pm 0,1$ & 1,1 & $48,2 \pm 0,4$ & 4,3 & $48,8 \pm 0,3$ & 10,1 \\
\hline
\end{tabular}

It was established that an increase in the leaf surface of a cultivated plant inhibits the development of segetal vegetation. Thus, according to Table 1 , the ratio of the weight of the green mass of soybean plants to the weight of the green mass of weeds in the variants treated with biological products increases in favor of the cultivated plant. That is, we can say about increasing the competitiveness of soybean in relation to segetals for the action of biological products.

Leaves, as is known, are the main organ of photosynthesis - the main source of biomass formation of plants, and therefore it is one of the determining factors for the formation of high yields [13].

As shown by studies with an increase in the area of the leaf surface, the total weight of weeds decreased, which ultimately contributed to increasing the yield of soybean crops (Table 2).

\begin{tabular}{|c|c|c|c|c|c|c|c|}
\hline \multirow[b]{2}{*}{ Option } & \multicolumn{3}{|c|}{ Yield, $\mathrm{t} / \mathrm{ha}$} & \multicolumn{3}{|c|}{ Yield increase, $t$ / ha } & \multirow{2}{*}{$\begin{array}{c}\text { Averag } \\
\text { e yield } \\
\text { increase, } \mathrm{t} \\
\text { / ha }\end{array}$} \\
\hline & $2015 p$. & $2016 \mathrm{p}$. & 2017 p. & $\begin{array}{l}2015 \\
\text { p. }\end{array}$ & $\begin{array}{l}2016 \\
\text { p. }\end{array}$ & $\begin{array}{l}2017 \\
\text { p. }\end{array}$ & \\
\hline Control & $\begin{array}{c}1,12 \pm 0,0 \\
6\end{array}$ & $\begin{array}{c}2,12 \pm 0,0 \\
1\end{array}$ & $\begin{array}{c}2,42 \pm 0,0 \\
6\end{array}$ & - & - & - & - \\
\hline \begin{tabular}{l}
\multicolumn{2}{c}{ Treatmen } \\
$\mathrm{t}$ with TD \\
"Enzim \\
Agro" \\
preparations
\end{tabular} & $\begin{array}{c}1,29 \pm 0,0 \\
4\end{array}$ & $\begin{array}{c}2,23 \pm 0,0 \\
3\end{array}$ & $\begin{array}{c}2,58 \pm 0,0 \\
2\end{array}$ & 0,17 & 0,11 & 0,16 & 0,15 \\
\hline $\begin{array}{l}\text { Treatmen } \\
\text { t with "BTU- } \\
\text { Center" } \\
\text { preparations }\end{array}$ & $\begin{array}{c}1,23 \pm 0,0 \\
2\end{array}$ & $\begin{array}{c}2,33 \pm 0,0 \\
2\end{array}$ & $\begin{array}{c}2,73 \pm 0,0 \\
4\end{array}$ & 0,11 & 0,21 & 0,31 & 0,21 \\
\hline
\end{tabular}


According to the results presented in the table, application of complexes of biologics in the conditions of organic agrotechnology influenced the increase of the soybean variety of the Suziria variety, which varied from 0.15 to $0.21 \mathrm{t} /$ ha in various experimental variants in relation to control, which was from 8 to $11 \%$.

\section{Conclusions}

Under the influence of biopreparations, the physiological processes of soy plants develop, which allows to increase the area of its leaf surface. In this case, soybeans actively compete with sesagel vegetation for living space, suppressing it. The result of stimulating the development of soy under the influence of biological drugs is to increase the yield of agricultural plant.

Thus, the use of a complex of biologics in the conditions of a transitional period to organic production contributes to increasing the competitiveness of a cultivated plant to weed groups and, consequently, stabilization of agroecosystems.

\section{Referens}

1. Ivashchenko O.O. (2004). Suchasni problemy herbolohii. [Modern problems of gerbology]. Visnyk ahrarnoi nauky. No. 3. P. 27 - 29. [in Ukrainian].

2. Zuza V.S., Hutianskyi R.A. (2008). Vplyv zaburianenosti na vrozhainist soi. [Effect of perturbation on soybean yield]. Visnyk ahrarnoi nauky. No. 1. P. 21 - 24. [in Ukrainian].

3. Svyrydov A.M., Panasenko O.L. (2014). Formuvannia vydovoho skladu burianiv v soievomu ahrofitotsenozi skhidnoho Lisostepu Ukrainy ta vplyv yikh shchilnosti na produktyvnist soi. [Formation of weed species composition in soybean agro-phytocoenosis of the eastern forest-steppe of Ukraine and the effect of their density on soybean productivity]. Naukovi pratsi Instytutu bioenerhetychnykh kultur $i$ tsukrovykh buriakiv. No. 20. P. 89 - 94. [in Ukrainian].

4. Tanchyk S.P., Salnikov S.M. (2014). Vynos elementiv zhyvlennia burianamy z gruntu ahrofitotsenozuburiakiv tsukrovykh. [The removal of nutrient elements from the soil of agrophytocenoses of sugar beetroot]. Naukovi pratsi Instytutu bioenerhetychnykh kultur i tsukrovykh buriakiv. No. 20. P. 105 - 110. [in Ukrainian].

5. Shevnikov M.la., Milenko O.H. (2015). Mizhvydova konkurentsiia ta zaburianenist posiviv soi zalezhno vid modeli ahrofitotsenozu. [Interspecific competition and soybean cropping of soybeans depending on the model of agrophytocenosis]. Visnyk ahrarnoi nauky Prychornomoria. V. 3 (86). P. 116 - 123. [in Ukrainian].

6. Olepir R.V. (2012). Vplyv elementiv ahrotekhniky vyroshchuvannia na produktyvnist soi. [Influence of agricultural cultivation elements on soybean productivity]. Zbirnyk naukovykh prats Instytutu bioenerhetychnykh kultur i tsukrovykh buriakiv. No. 14. P. 309 - 313. [in Ukrainian].

7. Fisjunov A.V. (1984). Sornye rastenija. [Weed plants ]. Moskva: Kolos. 320 p. [in Russian].

8. Metodicheskie rekomendacii po uchetu zasorennosti posevov i pochvy $v$ polevyh opytah. [Methodical recommendations on taking into account the contamination of crops and soil in field experiments]. Kursk: Ministerstvo sel'skogo hozjajstva SSSR. 1983. P. 45 - 58. [in Russian].

9. Veselovskyi I.V., Manko Yu.P., Kozubskyi O.B. (1994). Dovidnyk po burianakh. [Weed Directory]. Kyiv: Urozhai.. 145 p. [in Ukrainian].

10. Veselovskyi I.V., Lysenko V.K., Manko Yu.P. (1988). Atlas-vyznachnyk burianiv. [Atlas is a determinant of weeds]. Kyiv: Urozhai. 70 p. [in Ukrainian].

11. Hrytsaienko Z.M., Hrytsaienko A.O., Karpenko V.P. (2003). Metody biolohichnykh ta ahrokhimichnykh doslidzhen roslyn i gruntiv. [Methods of biological and agrochemical studies of plants and soils]. Kyiv: ZAT «Nichlava». 320 p. [in Ukrainian].

12. Dospehov B.A. (1985). Metodika polevogo opyta (s osnovami statisticheskoj obrabotki rezul'tatov issledovanij). 5-e izd., dop. i pererab. [Methods of field experience (with the basics of statistical 
processing of research results). 5th ed., Ext. and reclaim]. Moskva: AGROPromizdat. 351 p. [in Russian].

13. Kaminskyi V.F., Hliieva O.V. (2014). Ploshcha lystkovoho aparatu ta fotosyntetychna produktyvnist posiviv prosa za riznykh rivniv mineralnoho zhyvlennia. [The area of the puffer apparatus and the photosynthetic productivity of the crops of millet at different levels of mineral nutrition]. Zbirnyk naukovykh prats NNTs «Instytut zemlerobstva NAAN». V. 3. P. 79 - 84. [in Ukrainian].

14. Javaid A., Mahmood N. (2010). Growth, nodulation and yield response of soybean to biofertilizers and organic manures. Pakistan J. of Botany. T. 42. No. 2. P. $863-871$. 